Oḷegs Krasnopjorovs, Konstantīns Kovaļovs

\title{
Valsts atbalsta kritēriji uzṇēmumiem no produktivitātes veicināšanas aspekta
}

Covid-19 pandēmijas izraisītā ekonomikas lejupslīde ir palielinājusi valsts atbalsta apjomu mājsaimniecībām un uzṇēmumiem. Valsts konsolidētā kopbudžeta deficìtam 2021. gadā tuvojoties 9\% no iekšzemes kopprodukta (Finanšu ministrijas prognoze), katrs ceturtais iztērētais eiro ir aizṇemtā nauda. İstermiṇa krīzes gadījumā pat plaši atbalsta pasākumi uzṇēmumiem nepasliktinās valsts fiskālo ilgtspēju. Tomēr, paildzinoties krīzei, var pieaugt tieksme mērḳēt valsts atbalstu uzṇēmumiem. Šim atbalstam būtu arī jāveicina produktivitātes attīstỉba ilgtermiņā. Valsts atbalstu nevajadzētu novirzìt zombijuzņēmumiem, kuri nevar darboties bez pastāvīgas valsts iejaukšanās, jo ienākumu pārdale no produktīviem uz neproduktīiem uzņēmumiem negatīvi ietekmētu kopējo tautsaimniecības produktivitāti. Paturot to prātā, mēs sākām analizēt Latvijas uzṇēmumu mikrodatus, lai izvirzītu tādus kritērijus valsts atbalsta saṇemšanai, kas būtu noderīgi ilgtermiṇa produktivitātes attīstībā.

Pēdējo gadu laikā zinātniskajos pētijumos arvien plašāk tiek izmantoti mikrodati, kas saistīts gan ar lielāku šādu datubāzu pieejamību, gan ar lielākām datoru jaudām. Mikrodati sniedz iespēju veikt padziḷinātu izpēti par tēmām, par kurām agrāk bija pieejami vien̄̄gi agregētie dati. Piemēram, uzņēmumu mikrodatu izmantošana ḷauj analizēt produktivitāti tādās dimensijās, kurās agregētie dati nav pieejami, piemēram, uzñēmuma lielums, vecums un izvietojums.

ORBIS ir pasaulē lielākā datubāze uzṇēmumu līmenī, kas ārvalstīs tiek plaši izmantota akadēmiskajos pētījumos. Piemēram, 
Alviarez u. c. $(2020)^{1}$ novērtē uzṇēmumu produktivitātes nozìmi starpvalstu ienākumu atšķirībās. ESAO $(2019)^{2}$ novērtē, cik lielā mērā ES valstu digitālā transformācija ietekmēja uzṇēmumu produktivitātes dinamiku.

Pētījuma gaitā tika analizēti apmēram 167 tūkstoši ekonomiski aktīvo Latvijas uzņēmumu. ORBIS datubāzē iekl̦autie uzņēmumi ir reprezentatīvi gan nozaru dalījumā (izñēmums - valsts pārvalde, izglîtība un veselības aprūpe), gan Latvijas reǵionu dalījumā. Piemēram, ORBIS datubāzē ietvertie Latvijas uzñēmumi 2018. gadā aptvēra vairāk nekā 714 tūkstošus darba vietu, kas ir 79\% no darba vietu skaita valstī. Šajā pētījumā produktivitāte definēta kā pievienotā vērtība uz vienu strādājošo, savukārt pievienotā vērtība tika aprēķināta no uzņēmumu pel̦nas un personāla izmaksām (gadỉjumos, kad personāla izmaksu dati nebija pieejami, tika uzskatìts, ka personāla izmaksas ir 70\% no uzṇēmuma administratīvajām izmaksām; administratīvo izmaksu datu avots Lursoft datubāze). Lai no nomināliem ORBIS datubāzes rādītājiem (pārskata gada cenās) iegūtu reālus rādītājus (2015. gada cenās), tika lietots iekšzemes kopprodukta deflators. Šāds produktivitātes aprēķins ir plaši lietots zinātniskajā literatūrā (piemēram, Chevalier u. c., 2012³; Hadengue un Warrin, 20134; Barnett u. c., 20145).

Produktīvo uzņēmumu atlase tika veikta, izmantojot šādus produktivitāti ietekmējošus faktorus: uzṇēmuma vecums, lielums, pamatdarbības nozare un izvietojums. Šie faktori bieži tiek izmantoti akadēmiskajos pētijumos. Piemēram, De Kok u.c. (2006) ${ }^{6}$ novērtē kvadrātisko sakarību starp uzñēmuma vecumu un to produktivitāti. Coad u. c. (2016) ${ }^{7}$ pārbauda, vai jaunāki uzṇēmumi ir

1 Alviarez, V. I., Cravino, J., Ramondo, N. (2020). Firm-Embedded Productivity and Cross-Country Income Differences. NBER Working Papers 27915, National Bureau of Economic Research, Inc. Available: https:/www.nber.org/system/files/working_papers/w27915/w27915.pdf

2 OECD. (2019). Digitalisation and productivity: In search of the holy grail - Firm-level empirical evidence from EU countries. OECD Economics Department Working Paper Nr. 1533. Available: https:// doi.org/10.1787/18151973

3 Chevalier, P.-A., Lecat, R., Oulton, N. (2012). Convergence of Firm-Level Productivity, Globalisation, Information Technology and Competition: Evidence from France, Economics Letters, 116(2), pp. 1-44. Available: https://www.sciencedirect.com/science/article/abs/pii/S0165176512000626

4 Hadengue, M., Warrin, T. (2013). Patterns of Specialization and (Un)Conditional Convergence: The Cases of Brazil, China and India, CIRANO - Scientific Publications, 2013s-17, pp. 1-31. Available: https://papers.ssrn.com/sol3/papers.cfm?abstract_id=2326584

5 Barnett, A., Chiu, A., Franklin, J., Sebastia-Barrel, M. (2014). The Productivity Puzzle: A Firm-Level Investigation into Employment Behaviour and Resource Allocation Over the Crisis, Bank of England Working Paper No. 495, pp. 1-36. Available: https://www.bankofengland.co.uk/-/media/boe/files/working-paper/2014/the-productivity-puzzle-a-firm-level-investigation-into-employment.pdf

6 De Kok, J., Brouwer, P. (2006). On the relationship between firm age and productivity growth, Scientific Analysis of Entrepreneurship and SMEs, EIM Research Report No. H200617, 5-29. Available: https://www.researchgate.net/publication/5012594_On_the_relationship_between_firm_age_and_ productivity_growth

7 Coad, A., Segarra, A., Teruel, M. (2016). Innovation and firm growth: Does firm age play a role? Research Policy, 45(2), 387-400. Available: https://www.sciencedirect.com/science/article/abs/pii/S0048733315001687 
vairāk orientēti uz produktivitāti veicinošajiem inovatīviem risinājumiem. Cucculelli u. c. (2014) $)^{8}$ pēta uzñēmumu vecuma un īpašnieku ietekmi uz produktivitāti. Van Biesebroeck $(2005)^{9}$ secina, ka uzṇēmumiem ar lielāku darbinieku skaitu ir arī augstāka produktivitāte. Yang $(2020)^{10}$ salīdzina produktivitāti uzṇēmumiem, kas atrodas lielajās un mazajās pilsētās. Rizov un Walsh $(2010)^{11}$ analizē produktivitātes līmeni atkarībā no uzṇēmuma attāluma no galvaspilsētas.

Pētijumā tika secināts, ka produktivitāte ir pozitīvi saistīta ar uzṇēmuma lielumu un vecumu. Piemēram, lielajos uzņēmumos (vairāk par 250 darbiniekiem) produktivitāte ir uz pusi augstāka nekā mazajos (11-50 darbinieku). Turklāt uzṇēmuma pirmajos darbības gados produktivitātes līmenis parasti ir salīdzinoši zems, savukārt augstāks tas ir 10-15 gadu veciem uzṇēmumiem. Tomēr katrā uzṇēmumu grupā vērojama produktivitātes būtiska variācija. Tādējādi produktivitātes līmenis dažos mikrouzņēmumos (10 darbinieki un mazāk) ir augstāks nekā lielākajai daļai lielo uzņēmumu. Turklāt uzṇēmumu produktivitātes sadalijumam ir izteikta pozitīva asimetrija. Tas raksturo gadijumu, kad nelielam uzñēmumu skaitam ir l̦oti augsta produktivitāte, kas būtiski palielina vidējo produktivitātes rādītāju šajā uzṇēmumu grupā; savukārt lielākai uzņēmumu daļai produktivitāte ir zemāka par vidējo (t. i., produktivitātes mediāna ir zemāka par vidējo produktivitāti). İpaši izteikti tas tiek novērots lielo uzņēmumu grupā, kur trīs ceturtdaḷas strādājošo tiek nodarbināti uzṇēmumos ar produktivitāti mazāku par vidējo (1. attēls). Tādējādi var secināt: lai arī lielākiem un vecākiem uzṇēmumiem piemìt augstāka produktivitāte, uzṇēmuma vecums un izmērs nav izšḳirošie produktivitātes faktori.

Pētỉjuma rezultāti liecina, ka uznēèmumu produktivitāte ir pozitīi saistīta ar izvietojumu tuvāk Rīgai un citām republikas pilsētām. Piemēram, produktivitātes vidējais līmenis uzṇēmumam, kas atrodas desmit kilometru rādiusā no Rịgas centra, ir gandrīz divreiz augstāks nekā uzņēmumam, kas atrodas tālāk par simts kilometriem no Rīgas (2. attēls). Arī uzṇēmums, kas atrodas tuvāk par desmit kilometriem no republikas pilsētas, vidēji ir 1,6 reizes produktīvāks par

8 Cucculelli, M., Mannarino, L., Pupo, V., Ricotta, F. (2014). Owner-Management, Firm Age, and Productivity in Italian Family Firms, Journal of Small Business Management, 52 (2), 325-343. Available: https://www.tandfonline.com/doi/abs/10.1111/jsbm.12103

9 Van Biesebroeck, J. (2005). Firm Size Matters: Growth and Productivity Growth in African Manufacturing, Economic Development and Cultural Change, 53 (3), 545-583. Available: https://www.jstor.org/ stable/10.1086/426407?seq=1

10 Yang, Y., Mukhopadhaya, P., Yu, Z. (2020). Relationship between city size and firm productivity A new interpretation using the Chinese experience, Economic Modelling, Vol. 93, 546-558. Available: https://www.sciencedirect.com/science/article/abs/pii/S0264999320311937

11 Rizov, M., Walsh, P. P. (2011). Is There a Rural-UrbanDivide? Location and Productivity of UK Manufacturing, Regional Studies, 45 (5), 641-656. Available: https://www.tandfonline.com/doi/pdf/ 10.1080/00343401003713449?need Access=true 
1. attēls. Uzṇēmumu produktivitātes variācija atkarībā no uzṇēmuma lieluma un vecuma (vidēji 2015.-2019. gadā)

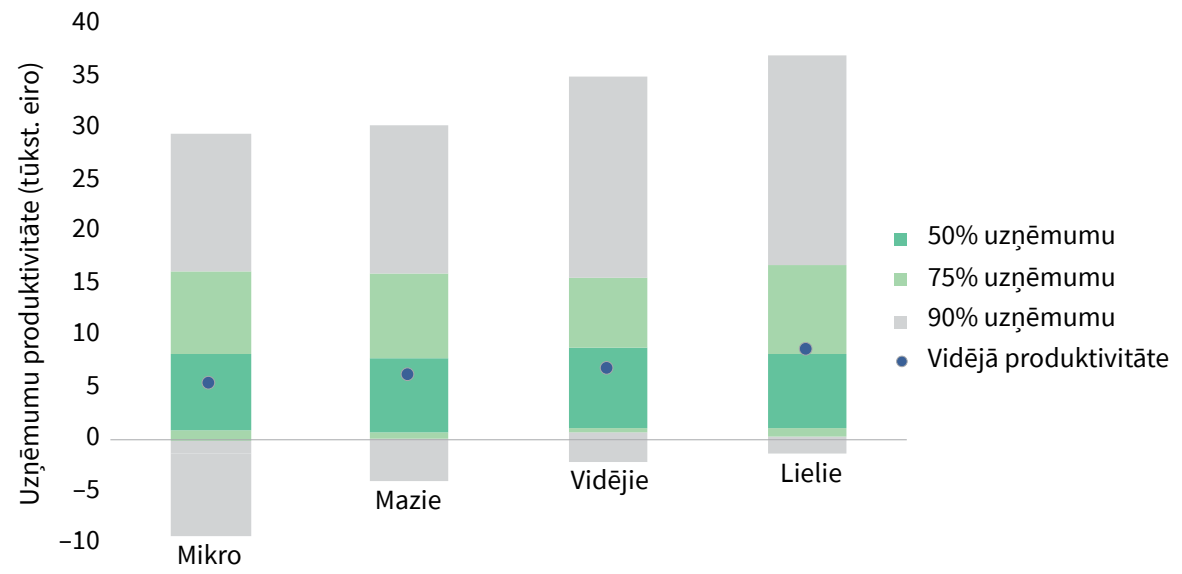

Uzñēmuma lielums

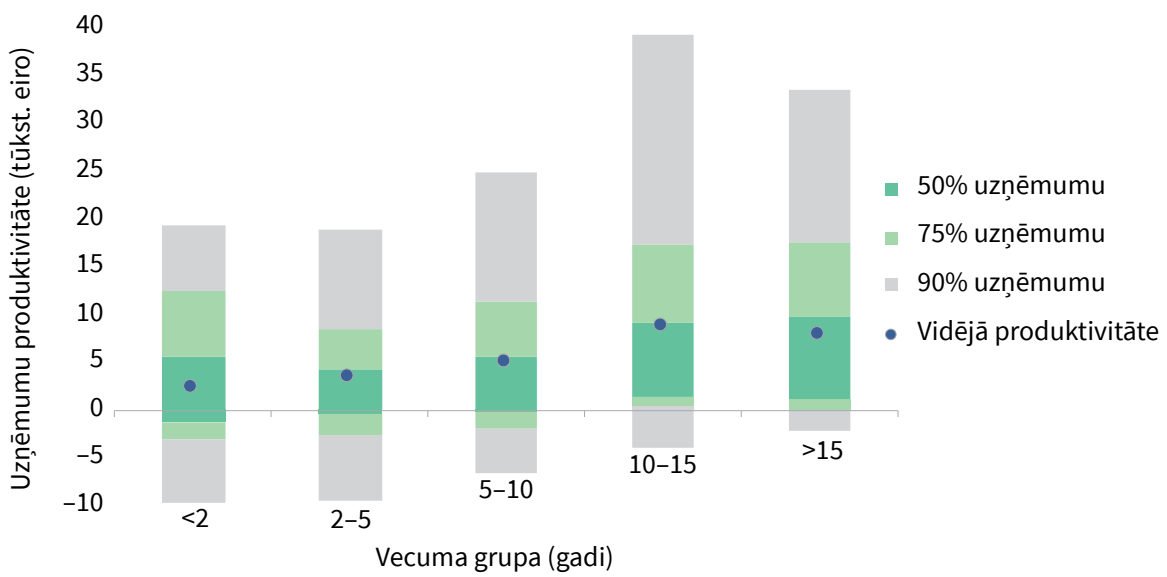

Piezīmes. Uzñēmumi sadalīti četrās grupās pēc darbinieku skaita: mikro (10 un mazāk darbinieku), mazie (11-50 darbinieku), vidējie (51-250 darbinieku), lielie (vairāk par 250 darbiniekiem). Attēlā redzams produktivitātes līmenis 50\%, 75\% un 90\% uzṇēmumiem (svērti pēc nodarbināto skaita) katrā grupā.

Avots: autoru aprēḳins pēc ORBIS datubāzes datiem.

uzṇēmumu, kas no republikas pilsētas atrodas tālāk par 50 kilometriem (3. attēls). Tomēr arī šajos gadījumos vērojama būtiska produktivitātes izkliede katra uzṇēmumu grupā, arī uzṇēmumu produktivitātes sadalījumam ir izteikta pozitīva asimetrija. Proti, gan Rīgā, gan citos reǵionos lielākajai daļai uzņēmumu produktivitāte ir zemāka par vidējo. 


\section{2. attēls. Uzṇēmumu produktivitāte atkarībā no attāluma līdz Rīgai}

(vidēji 2015.-2019. gadā)

a) uzṇēmumu produktivitātes variācija atkarībā no attāluma no Rīgas

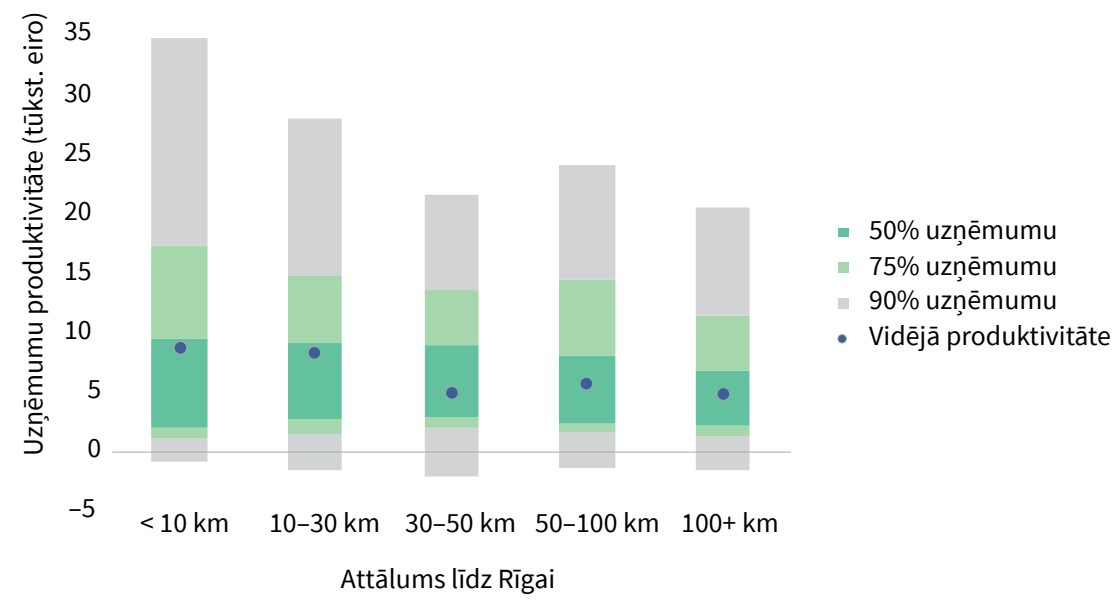

b) pasta indeksu teritoriju attālums no Rīgas (gaišāka krāsa apzīmē izvietojumu tuvāk Rīgai)

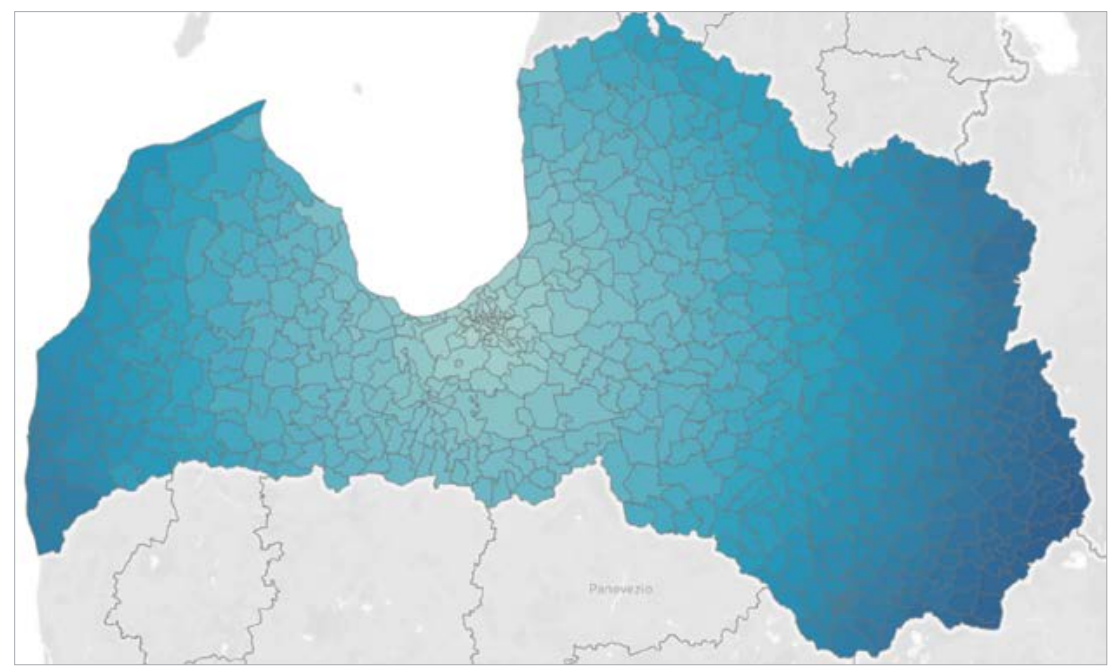

Piezīmes. Attēlā (a) redzams produktivitātes līmenis 50\%, 75\% un 90\% uzṇēmumiem katrā grupā. Uzñēmumi tika svērti pēc nodarbināto skaita.

Avots: autoru aprēķins pēc ORBIS, Lursoft un Google Cloud Geocoding API datiem. 
3. attēls. Uzṇēmumu produktivitāte atkarībā no attāluma līdz tuvākai republikas pilsētai (vidēji 2015.-2019. gadā)

a) uzṇēmumu produktivitātes variācija atkarībā no attāluma no tuvākās republikas pilsētas

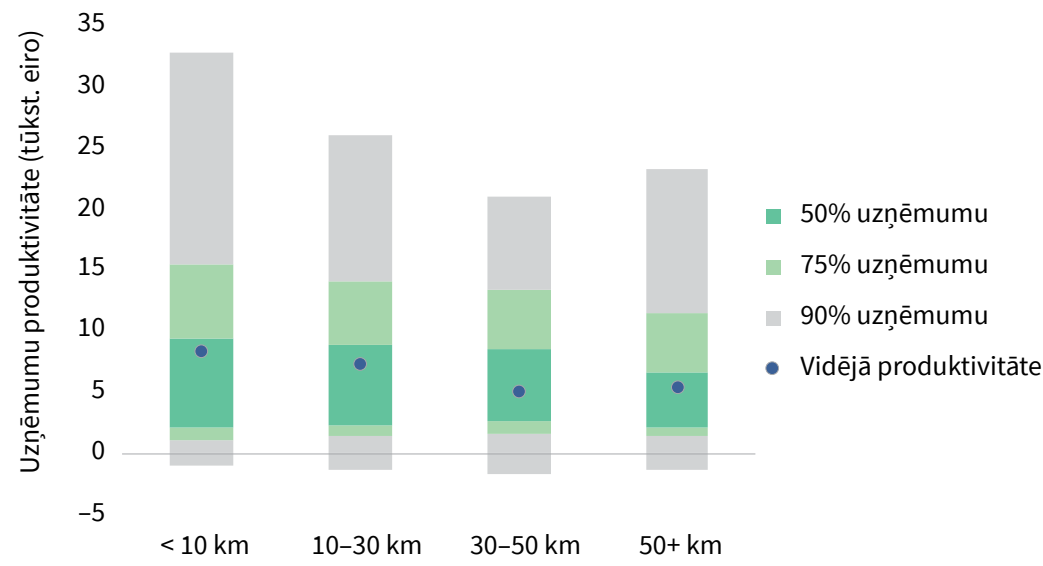

Attālums līdz tuvākai republikas pilsētai

b) pasta indeksu teritoriju attālums no tuvākās republikas pilsētas (gaišāka krāsa apzīmē izvietojumu tuvāk republikas pilsētām)

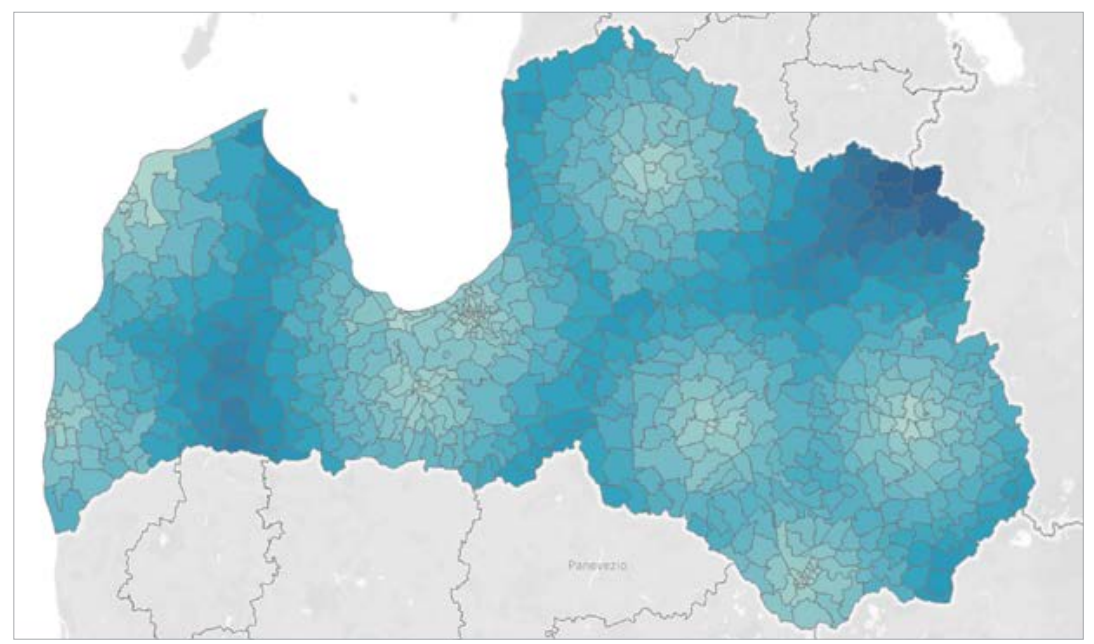

Piezīmes. Attēlā (a) redzams produktivitātes līmenis 50\%, 75\% un 90\% uzņēmumiem katrā grupā. Uzņēmumi tika svērti pēc nodarbināto skaita. 


\section{4. attēls. Apstrādes rūpniecības uzṇēmumu produktivitātes variācija apakšnozaru dalïjumā (vidēji 2015.-2018. gadā)}

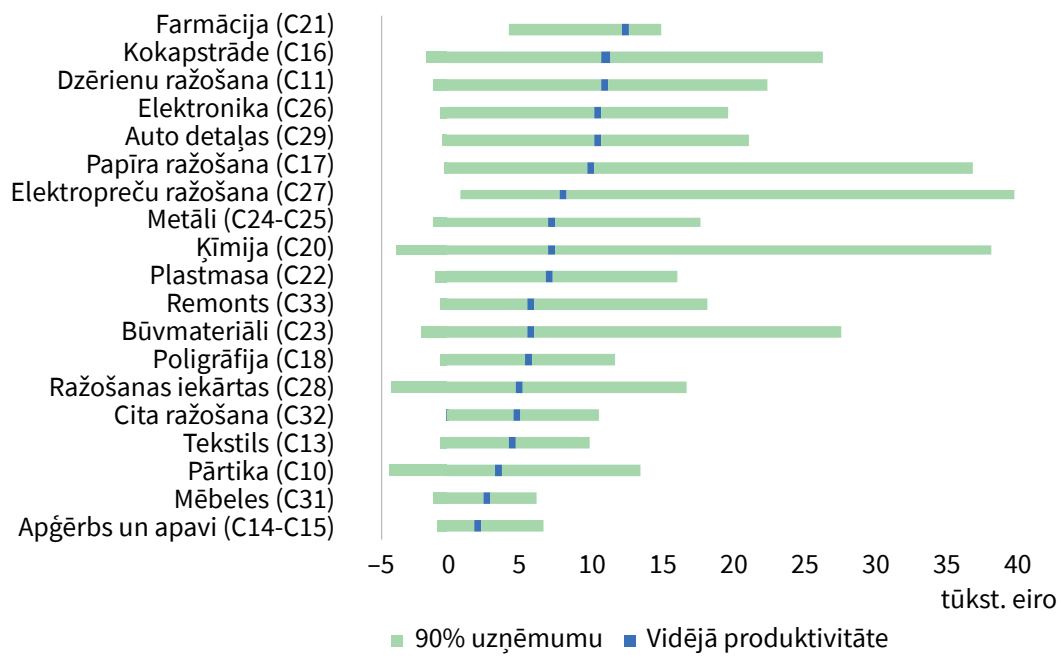

Piezīmes. Uzņēmumi tika svērti pēc nodarbināto skaita. Netika iekl̦auti šādi uzñēmumi (to izlecošās vērtības būtiski ietekmēja vidējo produktivitātes vērtību): SIA “Elme Messer Metalurgs”, SIA “I.S.D.” (kīimija C20), SIA "SCHWENK Latvija”, AS "Valmieras stikla šḳiedra” (būvmateriāli C23), AS "KVV Liepājas metalurgs" (metāli C24-25), SIA “EUROLCDS”, SIA “Mikrotīkls” (elektronika C26).

Avots: autoru aprēḳins pēc ORBIS datubāzes datiem.

Mūsu pētỉjuma rezultāti apstiprina arī to, ka produktivitāte būtiski atšķiras starp uzṇēmumiem pat vienas tautsaimniecîbas nozares un apakšnozares iekšienē. Piemēram, lai arī pārtikas rūpniecībai vidēji raksturīgs visai pieticīgs produktivitātes līmenis, vairākiem uzṇēmumiem produktivitāte pārsniedz kokapstrādes un farmācijas uzṇēmumu vidējo rādītāju (4. attēls).

Tālāk pētỉjuma gaitā tika uzbūvēti vairāki ekonometriskie modeḷi, lai analizētu visu iepriekšminēto faktoru vienlaicīgu ietekmi uz uzṇēmumu produktivitāti. Modeḷu rezultāti parāda, ka eksogēnie faktori - uzṇēmuma lielums, vecums, nozare un izvietojums - var izskaidrot tikai līdz 19\% no uzņēmumu produktivitātes atšķirībām. Tādējādi lielākā daļa no produktivitātes atšķirībām starp uzṇēmumiem ir saistīta ar uzņēmumu iekšējiem faktoriem.

Uzņēmumu produktivitātes līmenis ir noturīgs laikā. Tas nozīmē, ka šodien ir produktīvi tie uzṇēmumi, kas bija produktīvi vakardien (ar retiem izṇēmumiem); un tieši tie paši uzṇēmumi, visticamāk, uzrādīs augstu produktivitāti arī rìtdien. Piemēram, pastāv pozitīva un statistiski nozìmīga sakarība starp apstrādes rūpniecības uzṇēmumu produktivitāti 2016.-2018. gadā un šo uzṇēmumu 
produktivitāti 2013.-2015. gadā. To var redzēt, arī atlasot produktīvākos apstrādes rūpniecības uzṇēmumus 2018. gadā - arī iepriekšējos gados šie uzṇēmumi ("Mikrotīkls", "Kronospan Riga" u. c.) bija starp produktīvākajiem.

Tādējādi pamata kritērijs valsts atbalstam ir - vidējā termiṇā uzṇēmums bijis spējīgs nodrošināt augstāku produktivitāti nekā citi līdzīgi uzṇēmumi (tajā pašã lieluma un vecuma grupā, nozarē un lokācijā - attālumā no Rìgas un pārējām lielām pilsētām).

Šis pamatkritērijs nodrošina to, ka valsts atbalstu saṇem uzṇēmumi, kas nākotnē ar lielu iespējamību spēs uzrādīt augstu produktivitāti. Tieši šo uzṇēmumu pastāvēěana ir izšķiroši svarīga tautsaimniecības ekonomiskās attīstîbas potenciāla saglabāšanā. Valsts atbalsts netiek tērēts, lai iekonservētu ilgstoši neproduktīvus uzṇēmumus; tiem ḷauts ātri izbeigt saimniecisko darbỉbu un tādējādi atbrīvot ražošanas resursus produktīvāku uzṇēmumu vajadzībām. Tādējādi valsts atbalsts nepalielina zombijuzṇēmumu (no angḷu termina zombie companies) ìpatsvaru tautsaimniecībā un neatbalsta uzñēmumus, kuri nevar ilgtermiṇā funkcionēt bez atbalsta.

Zombijuzņēmumi un to ietekme uz nodarbinātību un produktivitāti tiek uzskatìti par vienu no Japānas ekonomiskās stagnācijas iemesliem 20. gadsimta 90. gados (Caballero u. c., 2008 ${ }^{12}$ ). Ir arī pierādījumi, ka zombijuzṇēmumu ìpatsvars ES dalībvalstīs kopš globālās finanšu krīzes ievērojami pieauga (Storz u. c.,

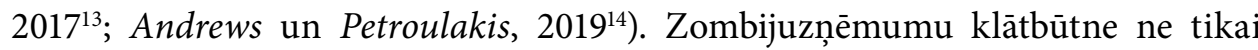
samazina vidējo produktivitātes līmeni tautsaimniecībā, bet arī bremzē produktīvo uzṇēmumu attīstîbu, samazinot to iespējas investēt, ieviest jauninājumus un pieñemt darbā jaunus darbiniekus (Peek un Rosengren, 200515; Caballero u. c., $\left.2008^{16}\right)$.

Vienlaikus pirmais kritērijs ņem vērā objektīvus iemeslus, kāpēc noteikta uzņēmuma produktivitāte ir augsta vai zema. Piemēram, šis kritērijs nosaka

12 Caballero, R., Hoshi, T., Kashyap, A. (2008). Zombie lending and depressed restructuring in Japan, American Economic Review, Vol. 98, No 5, pp. 1943-1977. Available: https://www.aeaweb.org/articles?id=10.1257/aer.98.5.1943

13 Storz, M., Koetter, M., Setzer, R., Westphal, A. (2017). Do we want these two to tango? On zombie firms and stressed banks in Europe, ECB Working Paper No. 2104. Available: https://www.ecb.europa.eu/ pub/pdf/scpwps/ecb.wp2104.en.pdf

14 Andrews, D., Petroulakis, F. (2019). Breaking the shackles: zombie firms, weak banks and depressed restructuring in Europe. ECB Working Paper No. 2240. Available: https://www.ecb.europa.eu/pub/pdf/ scpwps/ecb.wp2240 61e2d9dfec.en.pdf

15 Peek, J., Rosengren, E. (2005). Unnatural selection: Perverse incentives and the misallocation of credit in Japan. American Economic Review, Vol. 95, No. 4, pp. 1144-1166. Available: https://www.aeaweb.org/ articles?id=10.1257/0002828054825691

16 Caballero, R., Hoshi, T., Kashyap, A. (2008). Zombie lending and depressed restructuring in Japan, American Economic Review, Vol. 98, No. 5, pp. 1943-1977. Available: https://www.aeaweb.org/articles? id=10.1257/aer.98.5.1943 
to, ka valsts atbalsta pieškiršanas slieksnim (produktivitātes ziṇā) maziem uzṇēmumiem, kas atrodas tālu no Rīgas, vajadzētu būt zemākam nekā lieliem uzṇēmumiem tuvu Rīgai. Līdzīgi informācijas un komunikācijas pakalpojumu uzṇēmumiem slieksnim vajadzētu būt augstākam nekā izmitināšanas un ēdināšanas nozares uzṇēmumiem.

Akadēmiskajā diskusijā, vai valsts industriālajai politikai jāpielāgojas tautsaimniecības salīdzinošajai priekšrocībai (comparative advantage) vai arī jāmēgina to attīstìt vēlamā (nozaru ar augstu produktivitāti) virzienā (Lin un Chang, $2009^{17}$ ), pirmais kritērijs neatbalsta nevienu no šīm pieejām. Tā vietā, lai atbalstītu nozares, kurās Latvijai jau tagad ir salīdzinošā priekšrocība, vai arī augstās produktivitātes nozares, kurās Latvijai ir izredzes savu salīdzinošo priekšrocību attīstīt, pirmais kritērijs piedāvā atbalstīt uzņēmumus, kas savu augsto produktivitāti jau pierādījuši. Šim kritērijam ir divi pamatojumi, kas izriet no uzṇēmumu mikrodatu analīzes, izmantojot ORBIS datubāzi ${ }^{18}$. Pirmkārt, uzṇēmumu produktivitātes līmenis ir noturīgs laikā. Otrkārt, nozare (kā arī jebkurš faktors, pēc kura uzṇēmumi var tikt sadalīti grupās, - lielums, vecums, izvietojums) mēdz apvienot gan uzņēmumus ar augstu produktivitāti, gan uzn̦ēmumus ar zemu produktivitāti; tādējādi piederība pie noteiktas uzņēmumu grupas vēl negarantē augstu produktivitāti noteiktā uzṇēmumā.

Valsts atbalsta pieškiršanā prioritāte jādod uzņēmumiem ar lielāku iespējamību turpināt saimniecisko darbību (papildu kritērijs). ORBIS datubāzes analīze liecina, ka dažādiem uzṇēmumiem ir visai atšķirīga izdzīvošanas varbūtība - atkarībā no nozares, vecuma, lieluma vai produktivitātes rādītāja. Piemēram, lielāka varbūtība turpināt saimniecisko darbību ir gados vecākiem uzņēmumiem, uzṇēmumiem ar vismaz desmit darbiniekiem (5. attēls), kā arī apstrādes rūpniecỉbas uzṇēmumiem un uzṇēmumiem ar augstu produktivitāti.

Valsts atbalsta piešķiršanā prioritāte jādod arī tiem uzṇēmumiem, kuri ievērojamu daļu no saimnieciskās darbības veic teritorijās ar augstu bezdarba līmeni (papildu kritērijs). Tas ḷautu prioritizēt darba vietu saglabāšanu tajās pašvaldībās, kur tas visvairāk ir nepieciešams. Šis papildu kritērijs l̦aus uzṇēmumiem, kas veic saimniecisko darbību pašvaldībās ar augstu bezdarba līmeni, pretendēt uz valsts atbalstu pat tad, ja tā produktivitāte atrodas zem noteiktā sliekšņa.

Iepriekšminēto trīs valsts atbalsta kritēriju relatīvo svarīgumu var mainīt atkarībā no ekonomiskā cikla fāzes. Piemēram, darba vietu saglabāšanas aktualitāte pieaug ekonomiskās krīzes laikā - to var ṇemt vērā, palielinot trešā kritērija

17 Lin, J., Chang, H.-J. (2009). Should Industrial Policy in Developing Countries Conform to Comparative Advantage or Defy it? A Debate Between Justin Lin and Ha-Joon Chang. Development Policy Review, Vol. 27 (5), pp. 483-502. Available: https://doi.org/10.1111/j.1467-7679.2009.00456.x

18 https://amadeus.bvdinfo.com/ 


\section{5. attēls. Uzṇēmumu īpatsvars, kas turpināja saimniecisko darbību, pēc lieluma un} vecuma grupām (2012.-2018. gadā; \% no uzñēmumiem, kas veica saimniecisko darbību 2011. gadā)

a) pēc lieluma (darbinieku skaita)

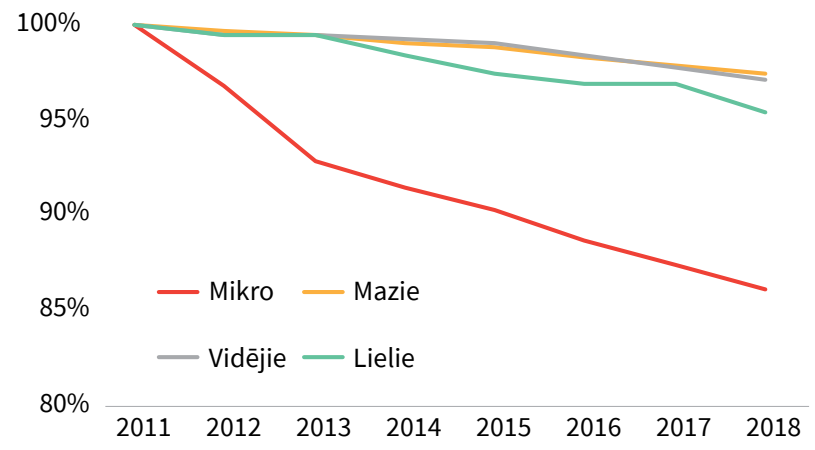

b) pēc vecuma grupas (gadi)

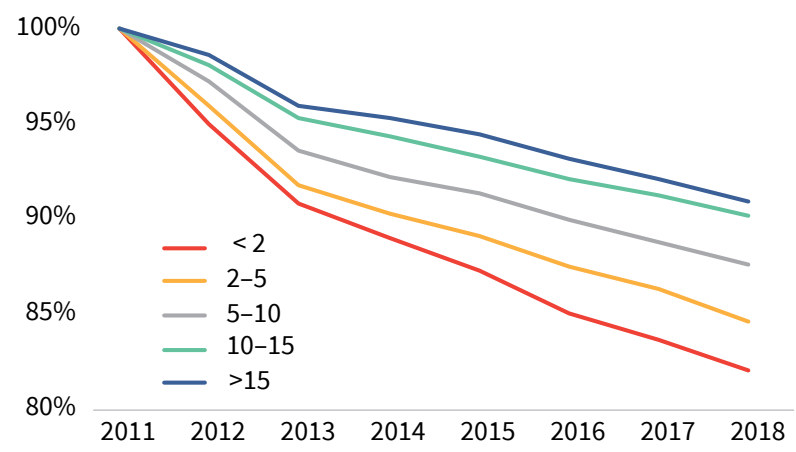

Piezīmes. (a) uzñēmumi sadalīti četrās grupās pēc darbinieku skaita: mikro (10 un mazāk darbinieku), mazie (11-50 darbinieku), vidējie (51-250 darbinieku), lielie (vairāk par 250 darbiniekiem). (b) uzņēmuma vecums attiecas uz 2011. gadu.

Avots: autoru aprēḳins pēc ORBIS datubāzes datiem.

svaru. Savukārt ekonomikas cikla ekspansijas fāzē lielāku aktualitāti iegūst tautsaimniecības attīstības tempu nodrošināšana ilgtermiņā, kuru var veicināt ar ražošanas faktoru pārdali par labu produktīvākiem uzn̦ēmumiem (t. i., palielinot pirmā kritērija svaru).

Tāpat valsts atbalsta kritērijos var iekḷaut arī uzṇēmumu eksportspēju un inovācijas, par kuriem dati šobrīd nav ietverti nevienā publiski pieejamā datubāzē. 